\title{
Spatial Narrative in Celeste Ng's Everything I Never Told You
}

\author{
Yuan Shen \\ University of Jinan \\ Jinan, Shandong, China
}

\author{
Mengna Xie \\ University of Jinan \\ Jinan, Shandong, China
}

\begin{abstract}
Celeste Ng employs spatial narrative to make Everything I Never Told You a multi-dimensional novel. This paper analyzes its spatial narrative in terms of the physical space, social space, spiritual space and textual space. Through the body and some other spatial images, the novelist constructs a suffocative micro-physical space that is in line with the anxiety and gloom felt by the characters. Through Marilyn's disillusionment and James' sense of alienation, the novelist introduces the social space about mixed marriages and the second wave of feminism in the late 20th century. Through the spiritual space, the subtle inner feelings of Marilyn, James and Lydia are unveiled. Through the textual space, non-linear narrative and intertextuality lends enchantment to the novel. Hence, the author enhances readability, flexibility and artistry of the novel by virtue of spatial narrative.
\end{abstract}

Keywords-Celeste Ng; Everything I Never Told You; spatial narrative

\section{INTRODUCTION}

Celeste $\mathrm{Ng}$, an American writer and novelist, who was born in the United States, graduated from Harvard University. In 2014, her debut Everything I Never Told You won the first place of the Amazon's best book of the year. Before winning the prize, she has written for many years, her novels and prose works more common in all kinds of literary journals.

Celeste $\mathrm{Ng}$ grew up in Pennsylvania and Ohio. Her parents are scientists, and they emigrated from Hong Kong to the United States in the 1960s. During her college years at the University of Michigan, $\mathrm{Ng}$ wrote a short story named What Passes Over which won the Hopwood Award in Graduate Short Fiction in 2006. Besides, Celeste Ng's short story Girls at Play won the 2012 trolley award. Her novels are published in One Story, TriQuarterly, Subtropics and other magazines.

Everything I Never Told You, Ng's first novel, is a literary thriller about an American family in Ohio in the 1970s (Chee, 2014: 1E). Celeste Ng spent six years writing this novel with four different drafts. In her writing on the first novel, $\mathrm{Ng}$ recorded racial discrimination suffered by herself as well as by her family and friends. Everything I Never Told You has also been translated into fifteen languages. The New York Times commented that the story had never been read in American novels, while the Los Angeles Times regarded it as an "excellent first novel about family, love, and ambition" (Tobar, 2014, 1C). Most critics interpret the novel from the perspectives of the race, gender, and ideals, thus touching the kernel with a realistic vein. But after reading this book, I want to analyze it from the perspective of space.

The concept of "space form" was first introduced in 1945 by literary critic Joseph Frank to the field of literary criticism. Since then, this concept began to be widely discussed and applied, and become one of the cornerstones of modern literary theory (Xue, 2010: 100). The Canadian theorist Northrop Frye once pointed out that "no matter what the structure of the literary works itself, it must be spatial in the opinion of the critics" (Michelle, 1980: 534). Frye also explored the space of literature in his article "Anatomy of Criticism" (1957). He believes that space includes four levels, which are physical, descriptive, structural and literary. The forms of spaces exist in literary works and show different forms in different literary styles. Therefore, the interpretation of the space in the article is very necessary in terms of literary understanding.

In the study of literature, the spatial form of literary works can't be ignored. Michelle pointed out that the spatial form is the basis of making history and time into a visible way. The space form helps us to make the essence of the literary experience more imaginable and concrete. Although space can't replace everything and can't tell us what the theme of a work is, the spatial form can help us understand how the topic is expressed, the narrator in which perspective to narrate the story, and how the images in the works constitute symbolic meanings (Michelle,1980: 536). On the other hand, the spatial form is a way of forming a defamiliarization in literary creation. The writer uses the spatial form to convey his aesthetic experience of art, increase the difficulty of feeling the art form, and enhance the effect of aesthetics (Xue, 2010: 103). Hence, the study of the space of literary works will help us to better understand the artistic nature of literary works.

In this novel, Celeste $\mathrm{Ng}$ uses a lot of different forms of space. First of all, as for physical space, she used a lot of space images, such as the kitchen, photos and rooms, which can reflect the social problems at that time. Secondly, in terms of social space, the mother Marilyn in this novel did not want to be a housewife, and even ran away from home to pursue her dream of being a doctor, which fully reflected the rise of feminism in the 1960s and 1970s. In addition, $\mathrm{Ng}$ 
used non-linear narrative in the textual space, combined with flashback, pre-writing and other writing techniques, thus forming a sense of time and space stagnation. To sum up, I intend to analyze Everything I Never Told You from the perspective of space, so that readers will have a more profound understanding of the purpose of the text and the unique features of the novel.

\section{PHYSICAL SPACE IN EVERYTHING I NEVER TOLD YOU}

\section{A. The Body}

The body is the smallest unit of space (Harvey, 2005: 289). Similarly, the body is the basis of other spatial scales and it is also connected to different parts of the network nodes. The body, as a spatial scale, has the particularity that other scales do not have, that is, other spatial scales are produced by the community, while the body has dual attributes both biological and social, which means that the individual's biological characteristics could be constructed and shaped by Social conditions (Tuan, 1977: 16). Thus, the body is involved in the whole process of social development and penetrates into the production of the family, the city and the country, and is shaped by social relations as well.

In Everything I Never Told You, Marilyn's body and destiny are closely linked with the society. In 1955, Marilyn was freshman at Radcliffe and took the course of physics, because she wanted to be a doctor. She is the only girl in the class and is sexually discriminated against from other classmates and even teachers. This is closely related to gender discrimination and the lack of feminist thought at that time. Marilyn studied hard and got high marks, which made the students and teachers look at her with admiration at last. But it is not easy for her to be a teacher. Although the employment rate of women has increased several times after World War II, women are struggling to get involved in industry, law, and doctors (Zhu, 2009: 341). This shows that the body is part of social development, and affected by the social atmosphere at the same time.

On the other hand, the study of the body is not only about the social relations, emotions, and culture carried by the body, but also focus on the actors' intuitive and active physical practice of the daily life. The body can be interpreted from three dimensions: the physical space, emotional space and metaphorical space. For physical space, the body is the place occupied by the individual. In terms of the emotional space, the body is the most closely produced scale to emotion, that is, the body is the carrier of emotion. The body is also affected by the emotional who impact the contact among individual, society, and space (Tao, 2015: 1183). In the emotional space, there is a clear expression of the close contact between the body and the emotion in Everything I Never Told You.

In 1966, Marilyn wanted to resume the dream of becoming a doctor after eight years. So she left home and went to Toledo to study alone. But before the exam, she suddenly felt dizzy. "Yet often, when she opened her books, Marilyn's mind whirled. Equations jumbled and rejumbled, hidden messages jumping out at her. $\mathrm{NaOH}$ became Nath, his small face wide-eyed and reproachful" $(\mathrm{Ng}, 2014$ : 138).
The changing of the body, made her think of the family, and she also had the feeling of homesick at first time. "Two weeks after she left home, she woke in her rented twin bed, her body one sharp ache. Suddenly she felt drowned in the incredible wrongness of the moment, that she should be here, so far away from them" (ibid). Marilyn was more homesick with frequent dizziness and physical pain, and began to reflect whether it was correct or not to run away from home. The frequent physical changes, which confirmed to be pregnant later, were closely linked with her emotional changes. To sum up, the body can be used as a carrier to reflect the emotional changes.

\section{B. Spatial Images}

The kitchen is a recurring image of space. In the novel, Marilyn and her mother felt exactly opposite for the kitchen. Marilyn's mother is a home ec teacher, and paid much attention to the family. She almost dedicated her whole life to the family and the kitchen. After the mother's death, Marilyn found that there was no trace of her mother except Betty Crocker cookbook. In the cookbook, the mother took notes, she wrote that "If you care about pleasing a manbake a pie. But make sure it's a perfect pie (Ng, 2014: 82). It can be seen that the mother is a traditional housewife at that age. However, Marilyn is very sick of the kitchen. She has been dreaming of becoming a doctor, not a housewife in the kitchen. She even refused to cook after coming back home, and would like to resist her own destiny through it. Two generations of women have completely different attitudes for the kitchen, which is closely related with the social space as well. Marilyn's mother was in the era when women were in a low position and did not get the right to work. Therefore, most of the women at that time would stay at home to take care of their husbands and children. But in the era of Marilyn, feminist movement has risen, and the employment rate of women has been greatly increased after World War II. In addition, Marilyn is an outstanding and proud person. So she does not want to be despised by others, and wants to get the same status as a man. Kitchen, as a small space, is the epitome of different social background for two generations.

The lake is also a very complex spatial image. It is an independent small space unit, which has a special meaning in the novel. Lydia was dead; her body was found in the lake. Why did she choose to drown herself in the lake? It may be traced back to a few years ago that Lydia had been pushed into the lake by Nath. "Lydia had felt relief so great she had signed in a deep choking lungful. That the weight of everything tilting toward her was too much" (Ng, 2014: 154). After being pushed into the lake, Lydia even felt relieved and relaxed, which she never had before. Lake can reflect the release of human stress to some extent. When people are surrounded by water, they may feel very free. Lydia could not afford the mother's expectation and the fear of losing Nath, so she wanted to get relief from the beginning and chose to jump into the lake to get a new life. Therefore, the lake is a complex spatial image, which represents the fear of death and depression on the one hand, but also a space that indicates the soul could be released. The lake in the novel has a pivotal position. 
In the novel, Marilyn often stays alone in her daughter's room after her daughter Lydia's death. This room is also a small space for Lydia to connect family and school life. In this space, you can find many traces of Lydia's family life, such as photos, diaries, etc. At the same time, it is also closely related with the school life, such as address book, school bags and textbooks. Among them, the photo is also a small space unit. Through a small photo, you can find the personal experience behind it. For example, the photo of Lydia's 16th birthday on which Lydia is smiling, though her face is turned toward the camera, her eyes are looking at something outside the photo's white border ( $\mathrm{Ng}, 2014: 14)$. However, we know that Lydia's mind is changing at that time in later chapter, "her perfectly made-up face smiled around the table, sweeping each of them in turn" $(\mathrm{Ng}, 2014$ : 239). From this little photo, we can appreciate the inner struggle and depression of Lydia. In order to make her parents happy, she has to use a smile to cover up the inner uneasiness. From these details, we learned why Lydia would choose to commit suicide. In addition, the address book can also be seen as an interpersonal space. Lydia has an address book, which records the phone numbers of her classmates, and she pretends to call her friends for a long time every day. But when Marilyn called Lydia's classmates, no one knew Lydia's whereabouts. This address book reflects the alienated and unfamiliar between Lydia and her classmates, and shows her loneliness as well.

In Everything I Never Told You, there are many large or small spatial images. These spaces are either independent or interrelated with other spaces, but they are all intended to better express the central idea of the novel. Through analyzing a small space, it can reflect the huge social space background.

\section{SOCIAL SPACE IN EVERYTHING I NEVER TOLD YOU}

\section{A. Immigration and Mixed Marriages}

The social space of the novel is a macro space. But it is essential for the reader to better understand the content of the novel. Celeste $\mathrm{Ng}$ sets the novel in a particular social space, where the text echoes the social reality and achieves that the art from reality and above reality.

In 1848, the gold mine was found in California which cause gold rush, and lead a lot of Chinese immigrates to the United States (Liang, 2011: 207). Initially, due to the urgent need for a lot of laborers for the development of the western region of the United States, the cheap laborers are generally welcomed by the United States. However, with the economic crisis in the eastern United States in 1873, a large number of unemployed workers from the east moved to the west to find work, and laborers became the major competitor to white job seekers. Since then, the United States laid down a series of laws and began to limit Chinese laborers to work in the United States. As mentioned in the novel, "America was a melting pot, but Congress, terrified that the molten mixture was becoming a shade too yellow, had banned all immigrants from China" (Ng, 2014: 40). So James' father came to California with a false name. It was because of the immigration policy at that time, and the attitude of white people, so James was excluded from other classmates. James desperately wants to get rid of immigrant labels and want to integrate into the American life. But the appearance of Asians makes him repeatedly frustrated. When he applied for Harvard to teach, he also suffered a failure because of ethnic problems. These early experiences of James are inseparable from the social reality at that time.

The plot of mixed marriages involved in the novel also engraves the mark of society. In 1958, James and Marilyn married in Boston, but "in Virginia, in half the country, their wedding would break the law. Even in Boston, she sometimes saw disapproval in the eyes of the passersby" $(\mathrm{Ng}$ 2014: 51). At that time, it is rare case that American white people married with other ethnic race, and it is even illegal in some areas. Until June 12, 1967, the US Supreme Court abolished the law of Virginia ban on American white people married with other ethnic. It was because mixed marriages were illegal in 1958 and was not accepted by most Americans, so Marilyn's mother was against the marriage. Her mother always said that "It's not right, Marilyn. It's not right" (Ng, 2014: 54), and "Think about your children. Where will you live? You won't fit in anywhere. You'll be sorry for the rest of your life" (ibid). The facts have proved that this mixed marriage is the source of the tragedy of this family. The people around them looked at James with their strange eyes, and their children did not escape the fate of being regarded as heterogeneous. Lydia has no friends, and she is excluded from the local culture and difficult to find her own identity. Under the circumstances, Lydia has to pretend to be able to adapt to the environment, pretend to have good friends, and pretend to enjoy a happy life. But her made-upface smile cannot conceal her solitude, which made people feel very poignant. Celeste described the American whites' hostility and prejudice against the Asian in the twentieth century through this novel, which is her personal experience. Mixed marriage is excluded and biased by people in a particular historical space, which may be one of the reasons leading to the tragedy.

\section{B. The Second Wave of Feminism}

"Feminism is a set of movements and ideological schools that share a common goal: to define, establish, and achieve equal political, economic, cultural, personal, and social rights for women" (Hawkesworth, 2006: 20). Since the 1960s, the second feminist movement has risen in the United States. The women opposed gender discrimination and strive for equal status and power with men. At the same time, they also criticized racist discrimination against feminist movements, and fight for racial equality. Marilyn, the heroine of the novel, is in this era.

Marilyn has a dream to be a doctor since her college years, but it was not easy. At that time, the status of women was low, and they were difficult to be doctors, lawyers and merchant, etc. Marilyn was the only girl in her class and she was ridiculed and discriminated by classmates and teachers. But she got the respect of others through her own efforts. However, her dream to be a doctor ended with pregnancy. And after eight years, Marilyn gained a legacy after his mother's death and she was influenced by the feminist thought at the time as well, so she decided to run away from 
home to pursue her dream. "In fact, Marilyn simply wants to finish her college degree and fulfill her self-realization as a doctor, which cannot be achieved unless she gets rid of her household duties" (Zhang, 2016: 30). In addition, there is another female figure who is also affected by the influence of feminism in the novel, that is, Dr. Woolf. She is Marilyn's neighbor, though she is a woman, she is a successful doctor as well, which not only prompted Marilyn to continue to pursue her dream, but also reflect the social space. In this social space of the second-wave of feminism, Marilyn will re-pursue her dream, which is inseparable from the social background.

\section{The Educational Environment}

In 1966, Marilyn once again gave up his doctor's dream because of pregnancy. Therefore, she will focus on Lydia's education, hoping her daughter can achieve her unimplemented dream. In 1975, "she saw glimmers of hope. Yale admitted women, then Harvard. The nation learned new words: affirmative action; Equal Rights Amendment; Ms" (Ng, 2014: 159). Marilyn felt very excited because of her daughter's bright future, and this opportunity is not easy. Although gender discrimination was inhibited by the influence of the second feminist movement, it was still very difficult for women to strive for equal access to education. The 20th century witnessed the great development of women's higher education in the United States, and the number of female college students in the school was increasing. Under the influence of this social background, Marilyn saw the hope. Therefore, she put all the expectations on Lydia and constantly cultivates her ability, which gave Lydia great mental stress. In the golden age of the development of higher education in the United States under the social space, which not only creates hope and equality, but also engenders great mental stress.

\section{THE CHARACTERS' SPIRITUAL SPACE}

\section{A. Marilyn's Ambition and Resignation}

In this novel, there is another important space, that is, the characters' spiritual space. Actually, this novel succeeds in describing characters. "Every character in the story is memorable and real. Readers learn everything about theminside an out, knowing what they look like and how much they hurt. Readers hear the thoughts and feelings of them and what they find is emotionally shattering" (Zhou, 2016: 170). The inner emotional change of a figure is also a small space unit, in which different people will show different emotions. Studying the spiritual space of the characters is also an important part of the space research.

Since Marilyn is one of the main characters in the novel, the author has a detailed description on her character and the inner world. Marilyn wanted to get rid of her mother's expectations from her childhood, and she did not want to be a traditional woman like her mother. On the contrary, she is eager to learn, wants to succeed, and achieve her own ideal of life. She has a great ambition that is to become a doctor. Although it is impossible for women to become a doctor at that time, and it is easy to be ridiculed by other people, she still don't change her mind. "She worked her way through chemistry, majored in physics, ticked the requirements for medical school off her list" (Ng, 2014: 30). Marilyn intended to fight back those who laugh at her with her own excellent results. At that time, it seemed that her dream was out of reach, but she kept on. Even after eight years, in the face of choice between family and dream she decided to run away from home to pursuit her dream. Being a doctor has been the greatest ambition in her life, which is the reasons why she chose her daughter to complete her unconsummated dream.

However, Marilyn encountered a lot of frustration and compromise in the pursuit of the ideal. Before graduating from college, pregnancy made Marilyn give up her dream. She left the college, became a housewife, and took care of the family and children. When she wanted to go out to work, James would gently persuade her to give up going out for work. In James's view, he did not want his wife to live a hard life like his mother, but hoping to give their families a good life. So Marilyn gave up her dream again for her husband. This can be deemed as the resignation of a woman who has to compromise for the family. Although after eight years of marriage, Marilyn finally determined to run away from home to pursue the dream, she had to give up once again because of pregnancy. At that time in 1966, it is still a long time from 1972 when the United States Supreme Court to cancel the legislation of prohibiting abortion, which means that Marilyn did not have the right to termination of pregnancy. She can no longer take care of the fetus and continue to study at the same time, so her dream of being a doctor has been completely disillusioned. She gave up her dream again and again for the family and children, which is also related to the unfair treatment of women at that time. After reading, it makes us feel Marilyn's deep helplessness and resignation.

\section{B. James' Silence and Inhibition}

Another distinctive character of the novel is the father James. He is always very silence, not good at communicating with people, and always in a state of repression. In the family and work, he is always silent, and also very alienated to his children. When he was a child, James learned to be silenced when his father came to the classroom to repair the window. He does not want people to look at him with ridicule, and do not want to be incompatible with others. But it turns out to be futile because he is an Asian. And the white people excluded Asians to a great extent with that social background. Therefore, he was treated as a heterogeneous when he was young. he was unable to integrate into the local life, and bore a variety of ridicule and exclusion. In this case, James became more and more silent, because apart from silence he had no other way to deal with this. Over time, he became accustomed to such life, or say that he had a compromise on life and society. Although when Nath had been ridiculed by others, he wanted to say that "he knew: what it was like to be teased, what it was like to never fit in" ( $\mathrm{Ng}, 2014$ : 92), he still chose to be silent.

At the same time, in the process of reading the novel, the reader can appreciate the inner pressure of James. He has talent and wants to teach at Harvard, but because of his Asian identity, he lost the opportunity. In his life, what he 
heard most is ridicule rather than appreciation. He always wants to get rid of the "other" status and eager to integrate into the white people's life, but was excluded at last. Therefore, he put his hopes on the child, hoping that the children can integrate into the white groups, and establish good interpersonal relationships. So he was particularly concerned about the relationship between Lydia and her classmates. The self-abasement and depressive feeling as a heterogeneous inferiority are always troubling him. Moreover, it is because of the inner repression that makes him want to gain understanding from his own Chinese assistant Louisa who has the same color and the same race with him, and make extramarital affairs. James' inner space is extremely depressing and inhibited, so he can only bear in silence, and to endure the depression as a heterogeneous. It has to say that James' personal tragedy is not only caused by this society, but also resulted from the unreleased inner space.

\section{Lydia's Solitude and Struggle}

Lydia is Marilyn's second child, and she has a special status at home. But her inner world is fraught with solitude and struggling. Eventually, she chose to die.

Lydia is lonely. First of all, as the crystallization of mixed marriage, she is a half-breed, and in the awkward position between whites and Asians. On the one hand, she could not find her own identity, and does not know which race she belongs to. On the other hand, as a heterogeneous, she was excluded by other white students in school, no one was willing to make friends with her, and she did not want to communicate with others. "Lydia's quietness, her lack of friends. Her recent sinking grades. And, in truth, the strangeness of her family. A family with no friends, a family of misfits" (Ng, 2014: 112). This environment, made Lydia feel more lonely. Secondly, Lydia's mother put her dreams on Lydia and wanted her daughter to achieve her unfinished dream. Due to her mother's leaving brought a huge trauma to Lydia, Lydia swore that as long as her mother comes back, she must be well obedient. So Lydia obeyed all the arrangements of her mother, and tried to play the role of good daughter, because she was afraid of losing her parents, and feeling lonely. Thirdly, Lydia's father James is very alienated from her, but very concerned about her interpersonal situation. He wants Lydia to have her own social circle like white people and be able to integrate into American society. So he gave Lydia a book about how to win friends and influence people as a gift on Lydia's birthday, and hoped that his daughter can get rid of Asian labels. In order not to disappoint his father, Lydia pretended to call her classmates for a long time every day. But in fact she did not have friends, and she just pretended to talk with people, which made her more lonely. Eventually, the fear of losing Nath made Lydia more solitary. Nath is "the one who understood the strange and brittle balance in their family. Who knew all that had happened. Who had always kept her afloat" (Ng, 2014: 273). But as Nath received a letter of acceptance from Harvard University, which meant Nath will leave her. Lydia felt that she was left alone and very solitary. Eventually, Lydia could not get rid of heavy stress and release the loneliness, so she chose to commit suicide.
Actually, Lydia has tried to resist. She does not want to live according to her mother's plan. With the arrival of adolescence and the increasing difficulty of academic studies Lydia began to realize how difficult it is for her to inherit her parents' dream. She also tried to carry out some resistance. She made friends with the bad boy Jack, who taught her to skip classes, have a date, and smoke. Once she lit the cigarette and put it to her lips. "The smoke burned in her lungs and made her head spin and suddenly she felt sharp and aware. Like cutting your finger, she thought: the pain, and the blood, reminded you that you were alive" $(\mathrm{Ng}$, 2014: 189). Lydia wanted to vent the inner pressure in this way and struggle with her destiny. But, in fact, she did not really confront parents. All the protests she did that her parents did not know and they did not seem to work. Therefore, Lydia struggled with fate, and chose to die at last.

The inner spaces of the three characters in the novel are a small individual space. The changes in inner space can affect a person's life and learning, thus affecting other spaces. Therefore, understanding the inner space of the characters is a very important part of the novel research.

\section{TeXtual Space in EVERYthing I NeVER Told You}

\section{A. Nonlinear Narrative}

Textual space is an indispensable space of writing novels, which mainly refers to how the author uses writing technique to construct space. In Everything I Never Told You, the two most obvious writing techniques are nonlinear narrative and intertextuality, which play important roles in the construction of textual space, and make the feature of textual space more obvious and more appealing to readers.

As Bieger said that "if one agrees that narration is in a most general sense a discursive, embodied component of human experience, space and place should, indeed, play a pertinent role in it -as motor, motif, and as structuring agents" (Bieger, 2016: 16). Nonlinear narrative is a special narrative technique, which is usually used in literary works and movies. The expression of the story will break the chronological order with the use of nonlinear narratives, not in accordance with the development of time but on the basis of the spatial order. The plot, characters, and scenes change with variational space. The author uses the linear narrative, flashback and other writing techniques, and she chooses to disorganize the chronological but highlight the space. At present, nonlinear narrative is more and more applied to literary works, such as Iris Murdoch's The Black Prince, Doris Lessing's The Golden Notebook, etc. Similarly, Celeste $\mathrm{Ng}$ uses nonlinear narrative to organize novels.

The novel is divided into 12 chapters. The first chapter introduces the death of Lydia and the process of police investigation. The second chapter begins with the question " How had it begun? Like everything: with mothers and fathers" (Ng, 2014: 25). The writer turns the transition from the death of Lydia to the acquaintance and romance of James and Marilyn, and accounts for the family background of them as well. From this chapter the author begins to break the limit of chronological order, and built a nonlinear spatial narrative structure. The contents of later chapters are also 
constantly transformed, interspersed some plots such as Marilyn's running away from home, Lydia's 16th birthday, James' extramarital, and Lydia's throwing herself into the lake. Although there are time changes between twelve chapters, the connections are natural and smooth. Celeste makes good use of some small space units such as photos, address books, diaries, and cookbooks to lead in new spaces and events. Celeste uses narrative techniques such as flashback, interjection and flash forward to explain the process of an event and show the relationship between an event and a person. Although many narrative clues are intertwined, it is not confusion. So the readers will gradually understand the life of James family, at the same time slowly approach to the truth of Lydia's death.

Although linear narrative novels are clearer and easier to understand than nonlinear narratives, nonlinear narrative has many special artistic effects. Firstly, nonlinear narrative can better sublimate the theme, and attract the reader's interest. The novel wrote at the beginning that "Lydia is dead. But they don't know this yet" (Ng, 2014: 1). In the beginning, the author has set the suspense to attract readers into the novel to find the truth between the reality and past. And it happens to be nonlinear narrative to achieve the effect of setting the suspense, attracting readers, and ultimately sublimate the theme. Secondly, the author uses nonlinear narrative to expand the amount of information in the novel. The linear narrative is often developed by a single clue. But nonlinear narrative breaks the chronological order, and makes the plot complex and changeable. As in the novel, the author enters another space just through a small photo to further introduce the story behind the photo. In this way, the author can better enrich the textual space of the novel with a small space, and the readers can get more information as well. Thirdly, nonlinear narrative makes the novel have the aesthetic function. It breaks the traditional narrative style and presents the novel in front of the reader with a fresh narrative structure. At the same time, it also makes the novel more interesting and flexible. In the process of reading, the readers are able to shuttle between the past and present, fantasy and reality, thus creating a special aesthetic effect.

\section{B. Intertextuality}

Intertextuality, as a new text theory, has emerged in recent years. Intertextuality was first proposed in 1969 by Kristeva in her book Semiotics. In this book, she mentioned that the text of any work is like a mosaic of many texts, and any text are the absorption and conversion of other texts (Kristeva, 1969: 55). In simple terms, intertextuality refers to the relationship between discourse or text and other discourse or text. Each text is not isolated, from the beginning of the production until it is taken; it takes the other text as a mirror and constitute the reference body of other text. Intertextuality can be divided into literary intertextuality and historical intertextuality.

Everything I Never Told You is interrelated with other literary works. The intertextuality of it, broadens the space of the novel and enriches the artistic connotation of the novel. The ending of the novel has a mental fit with Ian McEwan's Saturday (2006). Both of them express the silence after the anxiety, the hope after the pain, and the warmth after indifference, which sweeps away the sense of suffocation before. The sense of suffocation in the novel and the loneliness and depression that the characters felt are somewhat similar to Winesburg Ohio (1919) which also takes Ohio as a story background. The heroine Marilyn has the features of Nora who is the character of A Doll's House (1879). However her mentality is closer to the female college student Esther in The Bell Jar (1963) and the housewife Laura Brown in The Hours (1998). And Marilyn's unfulfillable dream seems correlate with Ma Maqi's giving up the violin dream because of her husband's opposition in The God of Small Things (1998), which shows the hardships of the married women to liberate themselves, pursue themselves, and realize themselves in a specific cultural context. In addition, Lydia is known as the darling of the James couple in this novel, which is similar to the young girl named "beloved", but was stifled by her mother in Beloved (1987). They both have the effect of irony. Amy and Isabel (1998) recounted the indifferent relationship between the sixteen-year-old girl Amy and her mother Isabel, and the anger of Isabel when she discovered the sexual secrets between Amy and her math teacher. The tension between Marilyn and Lydia in Everything I Never Told You reveals the communication dilemma faced by Amy and Isabel (Shen, 2016: 87).

On the other hand, Everything I Never Told You also bears the characteristics of historical intertextuality, that is, it forms the feature of dialogue with history. In the novel, Marilyn and James' marriage was illegal, which corresponded to the law of the ban on mixed marriages in Virginia. In addition, the plot that Marilyn insisted on pursuing her dream of being a doctor reflects the secondwave of feminism in the United States in the 1960s. From Marilyn, we see the feminist ideology that the American women pursued equality and freedom and against gender discrimination. In addition, as a Chinese, Celeste describes their own experience of being excluded from the Chinese perspective, and reflected in the novel by James, which corresponds to the immigration boom in the late 19th century.

In short, to a certain extent, intertextuality enables the reader to appreciate the mood of the characters more deeply in the process of constructing the pluralistic meaning of the text, and experience the fate of the characters in a broader text space, with the involvement of many pre-texts and historical backgrounds which further enhances the readability of the text. Eventually, the reader may sigh for the situation of the James family, but get a kind of aesthetic pleasure at the same time.

\section{CONCLUSION}

To sum up, the spatial form does exist in literary works, and it shows in different spatial states. The spatial form of literary works has its specific function, which makes the literary works form a kind of defamiliarization to enhance the aesthetic effect. In Everything I Never Told You, the author combines macro and micro spaces, which not only involves a wide range of social spaces, but also extends out a separate space from a photo. In this way, readers feel that the 
article layers are rich, and it will not always be confined to a particular space which people feel boring. At the same time, the author writes from the macro level to the micro level, and even meticulously describes a small photo or an address book, which allows readers not only to get richer information, but also praise the author's ingenuity. Through the changes and extension of different spaces, the characters in the novel are extremely lifelike. And the readers may feel their anxiety and fear to some extent. It is in this multi-space framework, the artistic expression layers of the novel are more abundant. At the same time, it also enhances the readability and flexibility of the work. Therefore, by virtue of these spaces, it is helpful for us to better understand the artistic beauty of the novel.

\section{REFERENCES}

[1] Bieger, Laura. Some Thoughts on the Spatial Forms and Practices of Storytelling [J]. Zeitschrift für Anglistik und Amerikanistik, 2016, 61 (1): 11-26.

[2] Chee, Alexander. Everything I Never Told You by Celeste Ng [N]. The New York Times, 2014-8-17: 1E.

[3] Harvey, David. Spaces of Hope [M]. Trans. Hu Daping. Nanjing: Nanjing UP, 2005.

[4] Hawkesworth, Mary. Globalization and Feminist Activism [M]. Lanham: Rowman \& Littlefield Publishers, 2006.

[5] Kristeva, Julia. Semantics: A Collection of Semianalysis [M]. Shanghiai: Fudan University Press, 2015.

[6] Liang, Xingli. Chinese Immigrants and Japanese Immigrants in the US "Asian Exclusion" Trend in the Late Twentieth Century and Early Nineteenth Century [J]. Journal of Northeast Normal University (Philosophy and Social Sciences), 2011, 253 (5): 207-209.

[7] Ng, Celeste. Everything I Never Told You [M]. New York: The Penguin Press, 2014.

[8] Tobar, Hector. Review "Everything I Never Told You" A Moving Tale of a Dysfunctional Family [N]. Los Angeles Times, 2014-6-17: $1 \mathrm{C}$.

[9] Tao, Wei, et al. The Body, the View of Body, and the Study of Body in Human Geography [J]. Geographical Research, 2015, 34 (6): 11731187.

[10] Tuan, Yifu. Space and Place: The Perspective of Experience [M]. Minnesota: University of Minnesota Press, 1977.

[11] Shen, Yuan. Unveiling Startling Secrets in Subtleties: On Celeste Ng's Everything I Never Told You [J]. Masterpieces Review, 533. 3 (2016): 86-88.

[12] Zhang, Ce. For Them the Bell Tolls: A Socialist Feminist Critique of Everything I Never Told You [D]. Nanjing: Nanjing Normal University, 2016.

[13] Zhou, Ting. Book Review of Everything I Never Told You [J]. Overseas English, 2016, 179 (20): 170-171.

[14] Zhu, Gang. Western Literary Theories in the Twentieth Century [M]. Beijing: Peking University Press, 2009.

[15] Xue, Yanli. On Spatial Forms in Literary Works [J]. Journal of University of Chang'an (Social Science Edition), 2010, 12 (2): 100103. 